\title{
Review \\ Review of Virus Inactivation by Visible Light
}

\author{
Martin Hessling *(1), Bernhard Lau and Petra Vatter
}

Institute of Medical Engineering and Mechatronics, Ulm University of Applied Sciences, 89075 Ulm, Germany; bernhard.lau@thu.de (B.L.); petra.vatter@thu.de (P.V.)

* Correspondence: martin.hessling@thu.de

\begin{abstract}
The COVID-19 pandemic is driving the search for new antiviral techniques. Bacteria and fungi are known to be inactivated not only by ultraviolet radiation but also by visible light. Several studies have recently appeared on this subject, in which viruses were mainly irradiated in media. However, it is an open question to what extent the applied media, and especially their riboflavin concentration, can influence the results. A literature search identified appropriate virus photoinactivation publications and, where possible, viral light susceptibility was quantitatively determined in terms of average log-reduction doses. Sensitivities of enveloped viruses were plotted against assumed riboflavin concentrations. Viruses appear to be sensitive to visible (violet/blue) light. The median log-reduction doses of all virus experiments performed in liquids is $58 \mathrm{~J} / \mathrm{cm}^{2}$. For the non-enveloped, enveloped and coronaviruses only, they were 222,29 and $19 \mathrm{~J} / \mathrm{cm}^{2}$, respectively. Data are scarce, but it appears that (among other things) the riboflavin concentration in the medium has an influence on the log-reduction doses. Experiments with DMEM, with its $0.4 \mathrm{mg} / \mathrm{L}$ riboflavin, have so far produced results with the greatest viral susceptibilities. It should be critically evaluated whether the currently published virus sensitivities are really only intrinsic properties of the virus, or whether the medium played a significant role. In future experiments, irradiation should be carried out in solutions with the lowest possible riboflavin concentration.
\end{abstract}

Keywords: enveloped virus; non-enveloped virus; coronavirus; photoinactivation; riboflavin; media

check for

updates

Citation: Hessling, M.; Lau, B.; Vatter, P. Review of Virus Inactivation by Visible Light. Photonics 2022, 9, 113. https://doi.org/10.3390/photonics 9020113

Received: 24 January 2022

Accepted: 13 February 2022

Published: 17 February 2022

Publisher's Note: MDPI stays neutral with regard to jurisdictional claims in published maps and institutional affiliations.

Copyright: (c) 2022 by the authors. Licensee MDPI, Basel, Switzerland. This article is an open access article distributed under the terms and conditions of the Creative Commons Attribution (CC BY) license (https:// creativecommons.org/licenses/by/ $4.0 /)$.

\section{Introduction}

The so far two-year rampant corona pandemic caused by the SARS-CoV-2 coronavirus, has not yet been halted despite all political, social, technical and medical measures. In fact, the latest "omicron" mutation has led to a global peak in new infections [1]. As a result, new approaches to virus reduction, among other things, must and will continue to be sought. Conventional disinfection techniques such as chemical disinfection or disinfection with ultraviolet radiation are very effective [2-6], but are not applicable in many everyday situations because, for example, ultraviolet radiation damages not only viruses but also human cells and various materials.

For bacteria and fungi, there have been many studies in recent years concerning the disinfecting effect of visible light. Blue and violet light are especially able to inactivate pathogenic bacteria and fungi [7-15] if the applied irradiation doses are high enough. Endogenous photosensitizers, such as porphyrins or flavins, naturally present in bacteria and fungi, absorb this visible light and subsequently generate reactive oxygen species such as ${ }^{1} \mathrm{O}_{2}, \mathrm{OH}$ or $\mathrm{H}_{2} \mathrm{O}_{2}$. These intracellular reactive oxygen species attack DNA, proteins or membranes and, if the produced damage becomes too great, the cell dies. Human cells also contain such photosensitizers, but they have nevertheless proven to be very resistant to visible light [16-24].

So far, it is assumed that viruses do not contain photosensitizers as bacteria or fungi do. Nevertheless, it is obvious to ask whether visible light might also have an inactivating effect on SARS-CoV-2 or other viruses. In fact, previous studies on the effect of light on viruses have actually observed a significant coronavirus reduction with the help of visible light. 
However, much of the experiments to date have been conducted with viruses in cell culture media, which may themselves contain photosensitizers such as riboflavin, that generate reactive oxygen species under illumination as reported by Grzelak et al. [25]. Riboflavin is of particular importance in this respect, as it's known strong antiviral effect is used in the disinfection of blood products. This is mostly undertaken in combination with UVB or UVA irradiation [26-31] —also against SARS-CoV-2 [32] - but virus inactivation with riboflavin also works with visible light [33].

Therefore, it cannot be excluded that media components influence virus photoinactivation results. Regardless, there are already commercial illumination devices that advertise white light, with partially increased short-wavelength (violet/blue) components, as safe measures against coronaviruses under a variety of different conditions in the air and on surfaces, based on currently published studies performed using viruses in media.

In the study presented here, the hitherto published results on the photoinactivating effect of visible light on viruses were collected and analyzed as far as possible. In particular, the question of whether the used media and their riboflavin content exhibit an influence on virus reduction was addressed.

\section{Materials and Methods}

The main focus of the present literature review was on inactivation studies of viruses by visible light. Photodynamic virus inactivation was excluded with the exception of investigations on viruses in solutions with a similar riboflavin concentration to that used in standard culture media such as DMEM and containing $0.4 \mathrm{mg}$ riboflavin per milliliter, this exception was made to better assess any influence of this known photosensitizer.

Searches were performed on Pubmed and Google Scholar for the following terms in various combinations: virus, phage, bacteriophage, inactivation, photoinactivation, disinfection, visible light, radiation, irradiation, blue, violet, $405 \mathrm{~nm}$, and riboflavin.

Where studies were found, the literature sources cited therein were searched for studies that could potentially be included. In addition, we checked whether the studies found were cited by other virus inactivation publications that also fit thematically and should therefore be included.

Where possible, attempts were made to quantify viral susceptibility using average log-reduction doses (irradiation dose for a $90 \%$ reduction). Sometimes the appropriate values were given in the text, otherwise we determined them by analyzing (enlarged) figures. If data sets were given, then a reduction of about 3 log-level was chosen and the average log-reduction dose was calculated on this basis.

To judge the potential influence of riboflavin, the riboflavin concentration was estimated in most studies. For distilled water and salt solutions such as phosphate buffered saline (PBS) the concentration was assumed to be $0.0 \mathrm{mg} / \mathrm{L}$. For (fresh) medium the typical concentrations, such as $0.4 \mathrm{mg} / \mathrm{L}$ for DMEM [34], $0.2 \mathrm{mg} / \mathrm{L}$ for RPMI 1640 [35] and $0.1 \mathrm{mg} / \mathrm{L}$ for MEM [36] were assumed. These media are often mixed with fetal calf serum (FCS) in concentrations between 2 and $10 \%$ or other components, but as long as it is mostly medium, the other components are ignored (for consumed medium it is assumed that the riboflavin is also mostly consumed).

For the calculation of median log-reduction doses and other analyses, only quantitative results in liquids, with riboflavin concentrations below $1 \mathrm{mg} / \mathrm{L}$, were included. Experiments with viruses on surfaces or within living cells were assumed to be incomparable to the result in saline solutions or media and therefore excluded in the analysis.

\section{Results}

About 30 appropriate studies were found during the literature search. They are listed in Table 1, divided into results for non-enveloped and enveloped viruses. The irradiation wavelengths and average log-reduction doses are given, if possible. Some of the retrieved studies are older than 50 years and were performed with different kinds of white lamps of unknown emission spectrum or spectrally resolved irradiance. In such 
cases, no quantitative assessment of the (violet/blue) light sensitivity by log-reduction dose was possible.

Table 1. Retrieved results for photoinactivation experiments with visible (violet/blue) light on non-enveloped (A) and enveloped viruses (B). Experimental conditions are given with the assumed riboflavin (RF) concentration and log-reduction dose, if available. If authors published results for a virus with different media or riboflavin concentrations, these are given one below the other. Results marked with * have been obtained on surfaces or at riboflavin concentrations above $1 \mathrm{mg} / \mathrm{L}$ and are not included in the further analysis.

\begin{tabular}{|c|c|c|c|c|}
\hline (A) Non-Enveloped Viruses & $\begin{array}{l}\text { Irradiation } \\
\text { Wavelength }\end{array}$ & $\begin{array}{l}\text { Medium during } \\
\text { Irradiation }\end{array}$ & $\begin{array}{l}\text { Assumed Riboflavin } \\
\text { Concentration }[\mathrm{mg} / \mathrm{L}]\end{array}$ & $\begin{array}{l}\text { 90\% Reduction Dose } \\
{\left[\mathrm{J} / \mathrm{cm}^{2}\right]}\end{array}$ \\
\hline \multirow[b]{2}{*}{$\begin{array}{l}\text { lambda phage } \\
\text { (dsDNA) }\end{array}$} & \multirow[b]{2}{*}{$410 \mathrm{~nm}$} & PBS + riboflavin & 18.8 & $4 *[37]$ \\
\hline & & PBS & 0 & $\begin{array}{c}\text { no reduction after } 5 \mathrm{~J} / \mathrm{cm}^{2} \\
{[37]}\end{array}$ \\
\hline $\begin{array}{l}\text { adenovirus } \\
\text { (dsDNA) }\end{array}$ & $420 \mathrm{~nm}$ & DMEM + FCS & 0.4 & $29[38]$ \\
\hline \multirow{4}{*}{$\begin{array}{l}\text { feline calcivirus } \\
\text { (ssRNA) }\end{array}$} & \multirow{4}{*}{$405 \mathrm{~nm}$} & $\begin{array}{c}\text { PBS + riboflavin }+ \\
\text { tyrosine, tryptophan, } \\
\text { pyridoxine and folic acid }\end{array}$ & 0.4 & $82[39]$ \\
\hline & & $\begin{array}{l}\text { nutrient rich medium } \\
(\mathrm{DMEM}+\mathrm{FCS}+\ldots)\end{array}$ & 0.4 & 88 [39] \\
\hline & & PBS + riboflavin & 0.4 & 329 [39] \\
\hline & & PBS & 0.0 & 719 [39] \\
\hline \multirow{2}{*}{$\begin{array}{l}\text { phi C31 } \\
\text { (dsDNA) }\end{array}$} & \multirow{2}{*}{$405 \mathrm{~nm}$} & nutrient rich medium & 0.2 & $113[40]$ \\
\hline & & PBS & 0.0 & $1021[40]$ \\
\hline $\begin{array}{l}\text { viral haemorrhagic septicaemia } \\
\text { virus } \\
\text { (ssRNA) }\end{array}$ & $405 \mathrm{~nm}$ & $\mathrm{~L} 15+\mathrm{FCS}$ & 0.1 & 114 [41] \\
\hline $\begin{array}{c}\text { encephalomyocarditis virus } \\
\text { (ssRNA) }\end{array}$ & $\begin{array}{c}405 \mathrm{~nm}+ \\
\text { blue/white }\end{array}$ & $\begin{array}{l}\text { DMEM + FCS + PBS } \\
\text { (ratio unknown) }\end{array}$ & $?$ & 178 [42] \\
\hline \multirow{2}{*}{$\begin{array}{c}\text { murine norovirus } \\
\text { (ssRNA) }\end{array}$} & \multirow{2}{*}{408 (cw laser) } & DMEM + riboflavin & 1.4 & $491 *[43]$ \\
\hline & & DMEM & 0.4 & $1976[43]$ \\
\hline \multirow{2}{*}{$\begin{array}{l}\text { tobacco mosaic virus } \\
\text { (ssRNA) }\end{array}$} & \multirow{2}{*}{ white light } & acetate buffer + riboflavin & 0.05 & reduction observed [44] \\
\hline & & acetate buffer & 0 & no reduction [44] \\
\hline \multirow{2}{*}{$\begin{array}{l}\text { Tulane virus } \\
\text { (ssRNA) }\end{array}$} & \multirow{2}{*}{$405 \mathrm{~nm}$} & $\begin{array}{c}\text { blueberry surface }+ \\
\text { riboflavin }\end{array}$ & & reduction [45] \\
\hline & & blueberry surface & & $\begin{array}{c}\text { no reduction after } \\
7.6 \mathrm{~J} / \mathrm{cm}^{2}[45]\end{array}$ \\
\hline $\begin{array}{l}\text { foot and mouth disease virus } \\
\text { (ssRNA) }\end{array}$ & $\begin{array}{l}\text { daylight and } \\
\text { artificial light }\end{array}$ & phosphate saline & 0 & medium reduction [46] \\
\hline $\begin{array}{c}\text { poliovirus type } 1 \\
\text { (ssRNA) }\end{array}$ & fluorescent lamp & gelatin saline & 0 & weak reduction [47] \\
\hline $\begin{array}{l}\text { human rhinovirus } 1 \mathrm{~b} \\
\text { (ssRNA) }\end{array}$ & $425 \mathrm{~nm}$ & DMEM + FCS & 0.4 & $\begin{array}{l}\text { no reduction after } \\
45 \mathrm{~J} / \mathrm{cm}^{2}[48]\end{array}$ \\
\hline $\begin{array}{l}\text { poliovirus type } 3 \\
\text { (ssRNA) }\end{array}$ & $\begin{array}{c}\text { white light of } \\
\text { incandescent bulb }\end{array}$ & medium 199 & 0.01 & no reduction [49] \\
\hline (B) Enveloped Viruses & $\begin{array}{l}\text { Irradiation } \\
\text { Wavelength }\end{array}$ & $\begin{array}{l}\text { Medium during } \\
\text { Irradiation }\end{array}$ & $\begin{array}{l}\text { Assumed Riboflavin } \\
\text { Concentration [mg/L] }\end{array}$ & $\begin{array}{c}90 \% \text { Reduction Dose } \\
{\left[\mathrm{J} / \mathrm{cm}^{2}\right]}\end{array}$ \\
\hline \multirow{4}{*}{$\begin{array}{c}\text { SARS-CoV-2 } \\
\text { (ssRNA, coronavirus) }\end{array}$} & \multirow{4}{*}{$425 \mathrm{~nm}$} & DMEM + FCS & 0.4 & $5[48]$ \\
\hline & & MEM + FCS & 0.1 & $18.8[48]$ \\
\hline & & inside vero cells & $?$ & $6.4 *[48]$ \\
\hline & & inside epithelial cells & $?$ & $6.7 *[48]$ \\
\hline $\begin{array}{c}\text { SARS-CoV-2 } \\
\text { (ssRNA, coronavirus) }\end{array}$ & $\begin{array}{l}410 \mathrm{~nm}+ \\
\text { blue/white }\end{array}$ & $\begin{array}{l}\text { MEM + FCS } \\
\text { (DMEM @ FOI } \\
\text { laboratory?) }\end{array}$ & 0.1 & $\begin{array}{c}6.5 \text { blue }(<490 \mathrm{~nm}) \\
12.6 \text { total irradiation [50] }\end{array}$ \\
\hline
\end{tabular}


Table 1. Cont.

\begin{tabular}{|c|c|c|c|c|}
\hline (B) Enveloped Viruses & $\begin{array}{l}\text { Irradiation } \\
\text { Wavelength }\end{array}$ & $\begin{array}{l}\text { Medium during } \\
\text { Irradiation }\end{array}$ & $\begin{array}{l}\text { Assumed Riboflavin } \\
\text { Concentration [mg/L] }\end{array}$ & $\begin{array}{c}90 \% \text { Reduction Dose } \\
{\left[\mathrm{J} / \mathrm{cm}^{2}\right]}\end{array}$ \\
\hline $\begin{array}{c}\text { SARS-CoV-2 } \\
\text { (ssRNA, coronavirus) }\end{array}$ & $\begin{array}{l}405 \mathrm{~nm}+ \\
\text { blue/white }\end{array}$ & DMEM & 0.4 & $6.6[51]$ \\
\hline $\begin{array}{c}\text { SARS-CoV-2 } \\
\text { (ssRNA, coronavirus) }\end{array}$ & $\begin{array}{c}405 \mathrm{~nm}+ \\
\text { blue/white }\end{array}$ & $\begin{array}{l}\text { DMEM + FCS + PBS } \\
\text { (ratio unknown) }\end{array}$ & $?$ & $7.5(<420 \mathrm{~nm})[42]$ \\
\hline $\begin{array}{c}\text { SARS-CoV-1 } \\
\text { (ssRNA, coronavirus) }\end{array}$ & $425 \mathrm{~nm}$ & DMEM + FCS & 0.4 & $9.9[48]$ \\
\hline \multirow{7}{*}{$\begin{array}{l}\text { feline infectious peritonitis virus } \\
\text { (ssRNA, coronavirus) }\end{array}$} & \multirow{7}{*}{$405 \mathrm{~nm}$} & DMEM + FCS & 0.4 & $14.1[52]$ \\
\hline & & metal wet & & $12 *[52]$ \\
\hline & & metal dry & & $20.3 *[52]$ \\
\hline & & paper wet & & $10.8 *[52]$ \\
\hline & & paper dry & & $13 *[52]$ \\
\hline & & plastic wet & & $14.4 *[52]$ \\
\hline & & plastic dry & & $31.8 *[52]$ \\
\hline $\begin{array}{c}\text { MERS-CoV } \\
\text { (ssRNA, coronavirus) }\end{array}$ & $425 \mathrm{~nm}$ & DMEM + FCS & 0.4 & $18.8[48]$ \\
\hline $\begin{array}{c}\text { influenza A virus } \\
\text { (ssRNA) }\end{array}$ & $\begin{array}{c}405 \mathrm{~nm}+ \\
\text { blue/white }\end{array}$ & $\begin{array}{l}\text { DMEM + FCS + PBS } \\
\text { (ratio unknown) }\end{array}$ & $?$ & $23.5[42]$ \\
\hline $\begin{array}{c}\text { respiratory syncytial virus } \\
\text { (ssRNA) }\end{array}$ & $420 \mathrm{~nm}$ & DMEM + FCS & 0.4 & $29[38]$ \\
\hline $\begin{array}{c}\text { SARS-CoV-2 } \\
\text { (ssRNA, coronavirus) }\end{array}$ & $420 \mathrm{~nm}$ & DMEM + FCS & 0.4 & $29[38]$ \\
\hline $\begin{array}{c}\mathrm{BCoV} \\
\text { (ssRNA, coronavirus) }\end{array}$ & $401 \mathrm{~nm}$ & DMEM + FCS & 0.4 & $29[53]$ \\
\hline $\begin{array}{c}\text { HCoV-229E } \\
\text { (ssRNA, coronavirus) }\end{array}$ & 405 nm (pulsed) & RPMI 1640 & 0.2 & $55[54]$ \\
\hline \multirow{2}{*}{$\begin{array}{c}\text { BCoV } \\
\text { (ssRNA, coronavirus) }\end{array}$} & \multirow{2}{*}{$405 \mathrm{~nm}$} & $\begin{array}{l}\text { (consumed) RPMI } 1640 \\
\text { diluted 1:10 in PBS } \\
\end{array}$ & 0 & $57.5[55]$ \\
\hline & & steel surface & & $96 *[55]$ \\
\hline $\begin{array}{c}\text { zika virus } \\
\text { (ssRNA) }\end{array}$ & $445 \mathrm{~nm}$ (cw laser) & unknown medium & $?$ & $64[56]$ \\
\hline $\begin{array}{c}\text { HCoV-229E } \\
\text { (ssRNA, coronavirus) }\end{array}$ & $405 \mathrm{~nm}$ & RPMI 1640 & 0.2 & 89 [54] \\
\hline $\begin{array}{l}\text { herpes simplex virus Type } 1 \\
\text { (dsDNA) }\end{array}$ & 445 nm (pulsed) & unknown medium & & 112 [57] \\
\hline $\begin{array}{c}\text { phi } 6 \\
\text { (dsRNA) }\end{array}$ & 405 & PBS/SMG & 0 & $400[58]$ \\
\hline $\begin{array}{c}\text { phi } 6 \\
\text { (dsRNA) }\end{array}$ & 455 & PBS & 0 & $2130[59]$ \\
\hline \multirow{2}{*}{$\begin{array}{l}\text { semliki forest virus } \\
\text { (ssRNA) }\end{array}$} & \multirow{2}{*}{$\begin{array}{l}\text { daylight and } \\
\text { fluorescent lamp }\end{array}$} & gelatin saline + riboflavin & 2 & very strong reduction [47] \\
\hline & & gelatin saline & 0 & strong reduction [47] \\
\hline $\begin{array}{l}\text { sindbis virus } \\
\text { (ssRNA) }\end{array}$ & $\begin{array}{c}\text { daylight and } \\
\text { fluorescent lamp }\end{array}$ & gelatin saline & 0 & strong reduction [47] \\
\hline $\begin{array}{l}\text { Murray Valley encephalitis virus } \\
\text { (ssRNA) }\end{array}$ & fluorescent lamp & gelatin saline & 0 & strong reduction [47] \\
\hline $\begin{array}{l}\text { transmissible gastroenteritis virus } \\
\text { (ssRNA, coronavirus) }\end{array}$ & daylight & unknown medium & $?$ & strong reduction [60] \\
\hline $\begin{array}{l}\text { influenza B virus } \\
\text { (ssRNA) }\end{array}$ & $\begin{array}{l}\text { daylight and } \\
\text { artificial light }\end{array}$ & phosphate saline & 0 & strong reduction [46] \\
\hline $\begin{array}{l}\text { vesicular stomatitis virus } \\
\text { (ssRNA) }\end{array}$ & $\begin{array}{l}\text { daylight and } \\
\text { artificial light }\end{array}$ & phosphate saline & 0 & strong reduction [46] \\
\hline $\begin{array}{l}\text { measles morbillivirus } \\
\text { (ssRNA) }\end{array}$ & $\begin{array}{c}\text { white light of } \\
\text { fluorescent lamp }\end{array}$ & salt solutions & 0 & strong reduction [61] \\
\hline \multirow{4}{*}{$\begin{array}{l}\text { herpes simplex virus } \\
\text { (dsDNA, JES strain) }\end{array}$} & \multirow{4}{*}{$\begin{array}{l}\text { white light of } \\
\text { fluorescent lamp }\end{array}$} & MEM & 0.1 & strong reduction [62] \\
\hline & & riboflavin solution & 0.1 & strong reduction [62] \\
\hline & & salt solutions & 0 & reduction [62] \\
\hline & & distilled water & 0 & no reduction [62] \\
\hline
\end{tabular}


Table 1. Cont.

\begin{tabular}{|c|c|c|c|c|}
\hline (B) Enveloped Viruses & $\begin{array}{l}\text { Irradiation } \\
\text { Wavelength }\end{array}$ & $\begin{array}{l}\text { Medium during } \\
\text { Irradiation }\end{array}$ & $\begin{array}{l}\text { Assumed Riboflavin } \\
\text { Concentration }[\mathrm{mg} / \mathrm{L}]\end{array}$ & $\begin{array}{l}90 \% \text { Reduction Dose } \\
{\left[\mathrm{J} / \mathrm{cm}^{2}\right]}\end{array}$ \\
\hline \multirow{3}{*}{$\begin{array}{l}\text { canine distemper virus } \\
\text { (ssRNA) }\end{array}$} & \multirow{3}{*}{$\begin{array}{l}\text { artificial visible } \\
\text { light }\end{array}$} & MEM & 0.1 & strong reduction [63] \\
\hline & & riboflavin solution & 0.1 & strong reduction [63] \\
\hline & & salt solutions & 0 & reduction [63] \\
\hline \multirow{2}{*}{$\begin{array}{l}\text { measles morbillivirus } \\
\text { (ssRNA) }\end{array}$} & \multirow{2}{*}{$\begin{array}{c}\text { white light of } \\
\text { incandescent bulb }\end{array}$} & Eagle's basal medium & 0.1 & strong reduction [49] \\
\hline & & distilled water & 0 & reduction [49] \\
\hline $\begin{array}{c}\text { murine leukaemia virus } \\
\text { (ssRNA) }\end{array}$ & $420-430 \mathrm{~nm}$ & OptiMEM & 0.1 & reduction [64] \\
\hline $\begin{array}{l}\text { rubella virus } \\
\text { (ssRNA) }\end{array}$ & $\begin{array}{c}\text { white light of } \\
\text { incandescent bulb }\end{array}$ & PBS & 0 & reduction [65] \\
\hline $\begin{array}{l}\text { influenza A virus } \\
\text { (ssRNA) }\end{array}$ & fluorescent lamp & gelatin saline & 0 & reduction [47] \\
\hline $\begin{array}{c}\text { parainfluenza virus type } 3 \\
\text { (ssRNA) }\end{array}$ & $\begin{array}{l}\text { white light of } \\
\text { fluorescent lamp }\end{array}$ & salt solutions & 0 & reduction [61] \\
\hline \multirow{2}{*}{$\begin{array}{c}\text { SARS-CoV-2 } \\
\text { (ssRNA, coronavirus) }\end{array}$} & \multirow[b]{2}{*}{$450,454,470 \mathrm{~nm}$} & inside vero cells & $?$ & reduction [66] \\
\hline & & $\mathrm{DMEM}+\mathrm{FCS}$ & 0.4 & $\begin{array}{c}\text { no reduction after } \\
20 \mathrm{~J} / \mathrm{cm}^{2}[66]\end{array}$ \\
\hline $\begin{array}{c}\text { Newcastle disease virus } \\
\text { (ssRNA) }\end{array}$ & $\begin{array}{l}\text { daylight and } \\
\text { artificial light }\end{array}$ & phosphate saline & 0 & weak reduction [46] \\
\hline $\begin{array}{l}\text { vaccinia virus } \\
\text { (dsDNA) }\end{array}$ & $\begin{array}{c}\text { white light of } \\
\text { incandescent bulb }\end{array}$ & Eagle's basal medium & 0.1 & weak reduction [49] \\
\hline $\begin{array}{l}\text { vaccinia virus } \\
\text { (dsDNA) }\end{array}$ & $\begin{array}{l}\text { daylight and } \\
\text { artificial light }\end{array}$ & phosphate saline & 0 & weak reduction [46] \\
\hline $\begin{array}{l}\text { influenza A virus } \\
\text { (ssRNA) }\end{array}$ & $\begin{array}{l}\text { daylight and } \\
\text { artificial light }\end{array}$ & phosphate saline & 0 & weak reduction [46] \\
\hline $\begin{array}{l}\text { fowl plague virus } \\
\text { (ssRNA) }\end{array}$ & $\begin{array}{l}\text { daylight and } \\
\text { artificial light }\end{array}$ & phosphate saline & 0 & no reduction [46] \\
\hline $\begin{array}{l}\text { rabbit pox virus } \\
\text { (dsDNA) }\end{array}$ & fluorescent lamp & gelatin saline & 0 & no reduction [47] \\
\hline
\end{tabular}

The median log-reduction doses of all virus experiments performed in liquids is $58 \mathrm{~J} / \mathrm{cm}^{2}$. For the non-enveloped, enveloped and coronaviruses only, they are 222,29 and $19 \mathrm{~J} / \mathrm{cm}^{2}$, respectively (results on surfaces or at riboflavin concentrations above $1 \mathrm{mg} / \mathrm{L}$ were ignored). The differences between these groups is also illustrated in the boxplot in Figure 1 .

A correlation between the assumed riboflavin concentration (or the applied media) and the sensitivity (inverse of the log-reduction dose) is illustrated in Figure 2A,B for all non-enveloped and enveloped virus data, respectively. The results for both groups, with those of enveloped viruses including those for all coronaviruses, show that sensitivity increases with higher riboflavin concentration. However, this tendency appears to be less pronounced for non-enveloped viruses. 


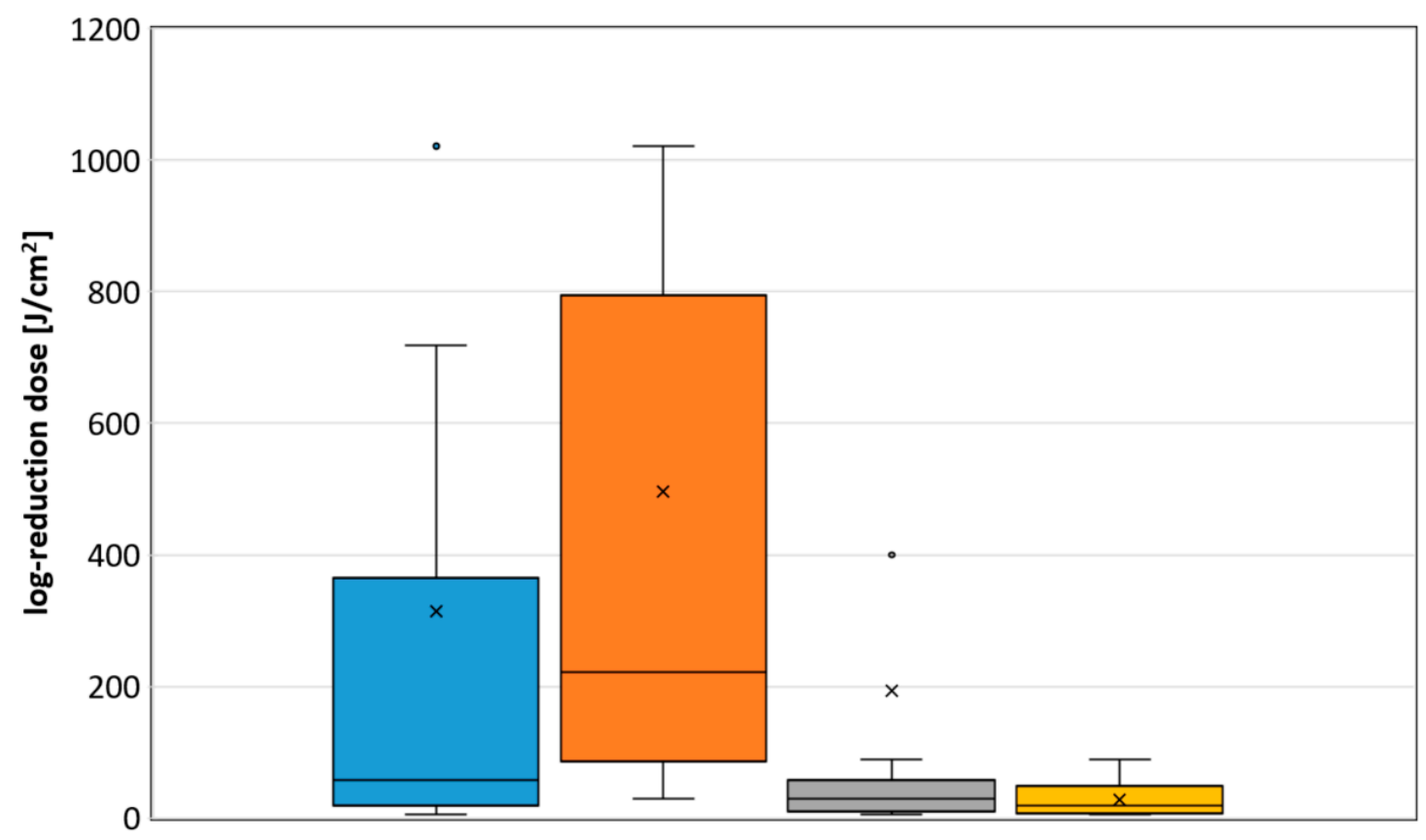

$\square$ all viruses (\#25) $\square$ non-enveloped viruses (\#10) $\square$ enveloped viruses (\#15) $\square$ coronaviruses (\#12)

Figure 1. Boxplot of the determined necessary log-reduction dose for all, non-enveloped, enveloped and coronaviruses. Illustrated are the medians, and the quantiles of the result distribution. The number in brackets give the quantity of data sets for each virus category (not all outliers are depicted).

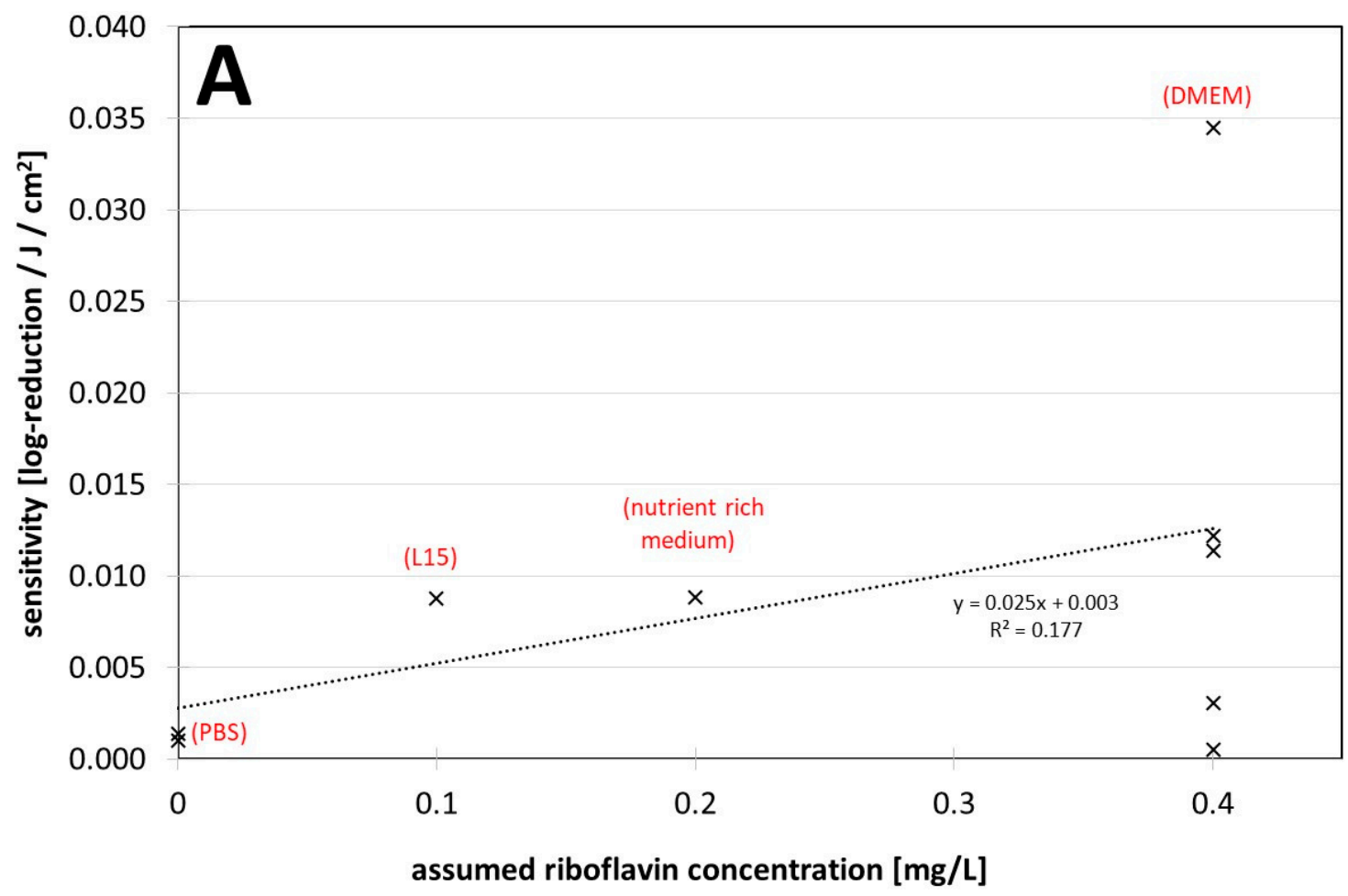

Figure 2. Cont. 


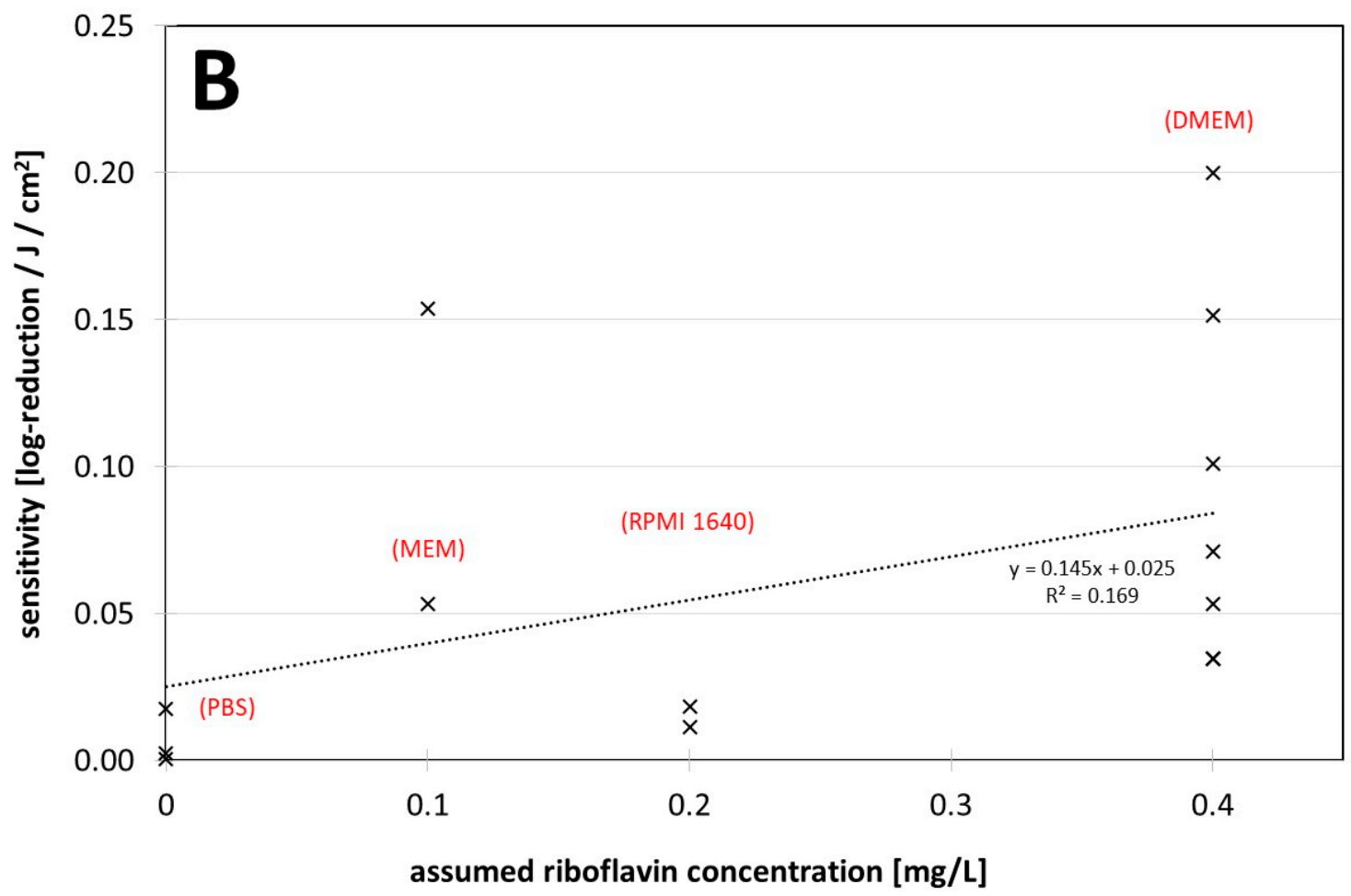

Figure 2. (A) Visible light sensitivity (inverse of the log-reduction dose) for viruses in different assumed riboflavin concentrations (media) for the non-enveloped viruses. (B) Visible light sensitivity for viruses in different assumed riboflavin concentrations (media) for enveloped viruses including coronaviruses. The dotted lines were derived by linear regression and are meant to visualize the dependence between riboflavin concentration (medium) and observed virus sensitivity.

\section{Discussion}

The overall impression from Table 1 and Figure 1 is that, although there are large differences between the various viruses and experimental conditions, viruses can be inactivated by visible violet or blue light. Enveloped viruses such as coronaviruses appear to be particularly sensitive and non-enveloped less sensitive.

The median log-reduction doses are roughly in the same order of magnitude as previously observed for bacteria and fungi $[14,15]$, although it is as yet unclear whether the mechanisms or photosensitizers are comparable.

However, there is a major difference in how the virus experiments are conducted. Irradiations of bacterial and fungal solutions occur predominantly in media such as PBS, which do not contain photosensitizers. In particular, irradiation experiments with animal or human viruses usually take place in cell culture media with additives such as FCS or even phenol red. The latter may lead to a lower irradiance than expected due to optical absorption in the violet/blue spectral region and should always be considered as Tomb et al. and Biasin et al. $[39,51]$ did.

Another aspect may be even more critical. Many of the recent (corona-) virus investigations consider the observed photoinactivation to be an intrinsic property of the viruses studied. However, the applied media contain at least one photosensitizer, riboflavin, which can make an appreciable contribution to inactivation. Most of the new coronavirus studies do not discuss this possibility. Rathnasinghe et al. have mentioned a comparative study with a riboflavin solution but published no results [42].

Riboflavin is known to act as a photosensitizer in combination with short wavelength visible light or with UV radiation. In photoinactivation experiments performed 50 years ago, it has already been found that the medium has an effect on virus reduction and that riboflavin concentrations, as found in common culture media, enhanced virus reduction $[44,47,49,62,63]$. This has been reconfirmed in more recent studies by 
Tomb et al. [39,40] and Kingsley [43,45] and also fits the results of Grezlak et al. [25] according to which irradiated media generate reactive oxygen species, for which riboflavin is mainly responsible.

This influence of riboflavin in the medium also does not seem to contradict the data presented here. Two of the three lowest log-reduction doses for violet/blue light in Table 1 are from coronavirus experiments with white LED light and with an appreciable blue irradiance around $450 \mathrm{~nm}$, the riboflavin absorption maximum.

The riboflavin concentrations in Figure 2 are only very roughly estimated and the data are sparse and scattered, but it already appears that irradiation experiments performed in DMEM with $0.4 \mathrm{mg} / \mathrm{L}$ riboflavin in the starting medium lead to higher photoinactivation sensitivities or smaller log-reduction doses compared with experiments in other media.

This is strongly supported by the fact that, in all results in Table 1 for a single virus but different riboflavin concentrations originating from a single paper, cell culture media, or riboflavin concentrations similar to cell culture media, led to lower log-reduction doses or higher photoinactiavation sensitivities than saline solutions with no or less riboflavin. This can be recognized very well in the mammalian virus experiments of Tomb et al. [39]. In pure PBS, the log-reduction dose was $719 \mathrm{~J} / \mathrm{cm}^{2}$. With $0.4 \mathrm{mg} / \mathrm{L}$ riboflavin the dose dropped to $319 \mathrm{~J} / \mathrm{cm}^{2}$ and in nutrient rich medium, it was even as low as $88 \mathrm{~J} / \mathrm{cm}^{2}$, which is almost a factor of 10 less than in the riboflavin-free solution. Also, in studies on a phage, Tomb et al. found approximately a factor of 10 in the log-reduction dose in solutions without riboflavin $\left(1021 \mathrm{~J} / \mathrm{cm}^{2}\right)$ and in nutrient medium $\left(113 \mathrm{~J} / \mathrm{cm}^{2}\right)$ [40]. This observation of the influence of the medium or the riboflavin concentration on the virus inactivation is quantitatively and qualitatively confirmed by several other authors $[37,43,45,48,49,62,63]$. In contrast, there is not one report with a higher log-reduction at lower riboflavin concentrations, when different concentrations or media were employed.

The question of the cause of the viral photosensitivity and the underlying mechanism of action remains unresolved. If exogenous photosensitizers in the medium, such as riboflavin, are responsible for the virus inactivation then it is a kind of photodynamic therapy (PDT), in which virus nucleotides, proteins, or the virus envelope are destroyed by reactive oxygen species $[67,68]$.

However, in saline solutions such as PBS, no external photosensitizers are expected and yet many authors have observed photoinactivation of viruses. This effect also still appears to be oxygen dependent $[63,65]$, which could be indicative of a mechanism based on endogenous photosensitizers and ROS generation. However, there are no known endogenous virus photosensitizers and no microbiological reason why viruses might require such photosensitizers.

Nonetheless, it has already been observed that typical PDT dyes can attach to viral envelopes [61]. This allows the speculation that viruses might inadvertently carry photosensitizers from their host cells, which contain mainly porphyrins and flavins. This would explain the particularly efficient effect of violet or blue light on viruses-especially enveloped viruses-and for example, the relationship between the antiviral effects of 405 and $455 \mathrm{~nm}$ as observed by Vatter et al. [59] for the phage phi6.

\section{Conclusions}

It appears that riboflavin, and also possibly other media components $[25,39,63]$ may have a major impact on photoinactivation results. DMEM especially might lead to higher virus sensitivities and should be used with caution in such experiments. Authors of future studies should consider this.

As long as it cannot be excluded that the medium has an influence on photoinactivation of (corona-) viruses, it should be mentioned in publications that virus reduction with visible light may be quite different under other conditions, such as in air. This is especially important in the ongoing corona pandemic, where frightened citizens seek protective measures and companies might offer deceptive security based on misunderstood studies. 


\begin{abstract}
Author Contributions: Conceptualization, B.L., P.V. and M.H.; methodology, B.L., P.V. and M.H.; validation, B.L., P.V. and M.H.; investigation, M.H.; resources, B.L. and M.H.; data curation, B.L., P.V. and M.H.; writing-original draft preparation, M.H.; writing-review and editing, B.L., P.V. and M.H.; project administration, B.L. and M.H.; funding acquisition, B.L. All authors have read and agreed to the published version of the manuscript.
\end{abstract}

Funding: We are very grateful for financial support by the Else-Kröner-Fresenius-Stiftung (2020_EKKP.140). The article processing charge was funded by the Baden-Württemberg Ministry of Science, Research, and Culture and the Ulm University of Applied Sciences in the funding program Open Access Publishing.

Institutional Review Board Statement: Not applicable.

Informed Consent Statement: Not applicable.

Data Availability Statement: All data is given in Table 1.

Conflicts of Interest: The authors declare no conflict of interest.

\title{
References
}

1. Coronavirus Resource Center. COVID-19 Dashboard: (Global Map). Available online: https://coronavirus.jhu.edu/map.html (accessed on 3 January 2022).

2. Kampf, G.; Todt, D.; Pfaender, S.; Steinmann, E. Persistence of coronaviruses on inanimate surfaces and their inactivation with biocidal agents. J. Hosp. Infect. 2020, 104, 246-251. [CrossRef] [PubMed]

3. Kampf, G.; Voss, A.; Scheithauer, S. Inactivation of coronaviruses by heat. J. Hosp. Infect. 2020, 105, 348-349. [CrossRef] [PubMed]

4. Kratzel, A.; Todt, D.; V'kovski, P.; Steiner, S.; Gultom, M.; Thao, T.T.N.; Ebert, N.; Holwerda, M.; Steinmann, J.; Niemeyer, D.; et al. Inactivation of Severe Acute Respiratory Syndrome Coronavirus 2 by WHO-Recommended Hand Rub Formulations and Alcohols. Emerg. Infect. Dis. 2020, 26, 1592-1595. [CrossRef] [PubMed]

5. Hessling, M.; Hönes, K.; Vatter, P.; Lingenfelder, C. Ultraviolet irradiation doses for coronavirus inactivation-Review and analysis of coronavirus photoinactivation studies. GMS Hyg. Infect. Control 2020, 15, 8. [CrossRef]

6. Hessling, M.; Hoenes, K.; Lingenfelder, C. Selection of parameters for thermal coronavirus inactivation-A data-based recommendation. GMS Hyg. Infect. Control 2020, 15, 16. [CrossRef]

7. Ashkenazi, H.; Malik, Z.; Harth, Y.; Nitzan, Y. Eradication of Propionibacterium acnes by its endogenic porphyrins after illumination with high intensity blue light. FEMS Immunol. Med. Microbiol. 2003, 35, 17-24. [CrossRef] [PubMed]

8. Guffey, J.S.; Wilborn, J. In vitro bactericidal effects of 405-nm and 470-nm blue light. Photomed. Laser Surg. 2006, 24, 684-688. [CrossRef]

9. Maclean, M.; MacGregor, S.J.; Anderson, J.G.; Woolsey, G. High-intensity narrow-spectrum light inactivation and wavelength sensitivity of Staphylococcus aureus. FEMS Microbiol. Lett. 2008, 285, 227-232. [CrossRef]

10. Feuerstein, O.; Ginsburg, I.; Dayan, E.; Veler, D.; Weiss, E.I. Mechanism of visible light phototoxicity on Porphyromonas gingivalis and Fusobacterium nucleatum. Photochem. Photobiol. 2005, 81, 1186-1189. [CrossRef]

11. Amin, R.M.; Bhayana, B.; Hamblin, M.R.; Dai, T. Antimicrobial blue light inactivation of Pseudomonas aeruginosa by photoexcitation of endogenous porphyrins: In vitro and in vivo studies. Lasers Surg. Med. 2016, 48, 562-568. [CrossRef]

12. Plavskii, V.Y.; Mikulich, A.V.; Tretyakova, A.I.; Leusenka, I.A.; Plavskaya, L.G.; Kazyuchits, O.A.; Dobysh, I.I.; Krasnenkova, T.P. Porphyrins and flavins as endogenous acceptors of optical radiation of blue spectral region determining photoinactivation of microbial cells. J. Photochem. Photobiol. B 2018, 183, 172-183. [CrossRef] [PubMed]

13. Cieplik, F.; Spath, A.; Leibl, C.; Gollmer, A.; Regensburger, J.; Tabenski, L.; Hiller, K.-A.; Maisch, T.; Schmalz, G. Blue light kills Aggregatibacter actinomycetemcomitans due to its endogenous photosensitizers. Clin. Oral Investig. 2014, 18, 1763-1769. [CrossRef] [PubMed]

14. Hessling, M.; Spellerberg, B.; Hoenes, K. Photoinactivation of bacteria by endogenous photosensitizers and exposure to visible light of different wavelengths-A review on existing data. FEMS Microbiol. Lett. 2016, 364, fnw270. [CrossRef]

15. Tomb, R.M.; White, T.A.; Coia, J.E.; Anderson, J.G.; MacGregor, S.J.; Maclean, M. Review of the Comparative Susceptibility of Microbial Species to Photoinactivation Using 380-480 nm Violet-Blue Light. Photochem. Photobiol. 2018, 94, 445-458. [CrossRef]

16. Kleinpenning, M.M.; Smits, T.; Frunt, M.H.A.; van Erp, P.E.J.; van de Kerkhof, P.C.M.; Gerritsen, R.M.J.P. Clinical and histological effects of blue light on normal skin. Photodermatol. Photoimmunol. Photomed. 2010, 26, 16-21. [CrossRef]

17. McDonald, R.S.; Gupta, S.; Maclean, M.; Ramakrishnan, P.; Anderson, J.G.; Macgregor, S.J.; Meek, R.M.D.; Grant, M.H. 405 nm Light exposure of osteoblasts and inactivation of bacterial isolates from arthroplasty patients: Potential for new disinfection applications? Eur. Cell. Mater. 2013, 25, 204-214. [CrossRef] [PubMed]

18. Wang, T.; Dong, J.; Yin, H.; Zhang, G. Blue light therapy to treat candida vaginitis with comparisons of three wavelengths: An in vitro study. Lasers Med. Sci. 2020, 35, 1329-1339. [CrossRef]

19. Liebmann, J.; Born, M.; Kolb-Bachofen, V. Blue-light irradiation regulates proliferation and differentiation in human skin cells. J. Investig. Dermatol. 2010, 130, 259-269. [CrossRef] 
20. Bumah, V.V.; Masson-Meyers, D.S.; Awosika, O.; Zacharias, S.; Enwemeka, C.S. The viability of human cells irradiated with 470-nm light at various radiant energies in vitro. Lasers Med. Sci. 2021, 36, 1661-1670. [CrossRef]

21. Makdoumi, K.; Hedin, M.; Bäckman, A. Different photodynamic effects of blue light with and without riboflavin on methicillinresistant Staphylococcus aureus (MRSA) and human keratinocytes in vitro. Lasers Med. Sci. 2019, 34, 1799-1805. [CrossRef]

22. Ramakrishnan, P.; Maclean, M.; MacGregor, S.J.; Anderson, J.G.; Grant, M.H. Differential sensitivity of osteoblasts and bacterial pathogens to 405-nm light highlighting potential for decontamination applications in orthopedic surgery. J. Biomed. Opt. 2014, 19, 105001. [CrossRef] [PubMed]

23. Dai, T.; Gupta, A.; Huang, Y.-Y.; Yin, R.; Murray, C.K.; Vrahas, M.S.; Sherwood, M.E.; Tegos, G.P.; Hamblin, M.R. Blue light rescues mice from potentially fatal Pseudomonas aeruginosa burn infection: Efficacy, safety, and mechanism of action. Antimicrob. Agents Chemother. 2013, 57, 1238-1245. [CrossRef] [PubMed]

24. Zhang, Y.; Zhu, Y.; Gupta, A.; Huang, Y.; Murray, C.K.; Vrahas, M.S.; Sherwood, M.E.; Baer, D.G.; Hamblin, M.R.; Dai, T. Antimicrobial blue light therapy for multidrug-resistant Acinetobacter baumannii infection in a mouse burn model: Implications for prophylaxis and treatment of combat-related wound infections. J. Infect. Dis. 2014, 209, 1963-1971. [CrossRef] [PubMed]

25. Grzelak, A.; Rychlik, B.; Bartosz, G. Light-dependent generation of reactive oxygen species in cell culture media. Free Radic. Biol. Med. 2001, 30, 1418-1425. [CrossRef]

26. Ruane, P.H.; Edrich, R.; Gampp, D.; Keil, S.D.; Leonard, R.L.; Goodrich, R.P. Photochemical inactivation of selected viruses and bacteria in platelet concentrates using riboflavin and light. Transfusion 2004, 44, 877-885. [CrossRef] [PubMed]

27. Marschner, S.; Goodrich, R. Pathogen Reduction Technology Treatment of Platelets, Plasma and Whole Blood Using Riboflavin and UV Light. Transfus. Med. Hemother. 2011, 38, 8-18. [CrossRef]

28. Faddy, H.M.; Prow, N.A.; Fryk, J.J.; Hall, R.A.; Keil, S.D.; Goodrich, R.P.; Marks, D.C. The effect of riboflavin and ultraviolet light on the infectivity of arboviruses. Transfusion 2015, 55, 824-831. [CrossRef]

29. Faddy, H.M.; Fryk, J.J.; Watterson, D.; Young, P.R.; Modhiran, N.; Muller, D.A.; Keil, S.D.; Goodrich, R.P.; Marks, D.C. Riboflavin and ultraviolet light: Impact on dengue virus infectivity. Vox Sang. 2016, 111, 235-241. [CrossRef]

30. Elikaei, A.; Hosseini, S.M.; Sharifi, Z. Inactivation of model viruses and bacteria in human fresh frozen plasma using riboflavin and long wave ultraviolet rays. Iran. J. Microbiol. 2017, 9, 50-54.

31. Callahan, S.M.; Wonganan, P.; Obenauer-Kutner, L.J.; Sutjipto, S.; Dekker, J.D.; Croyle, M.A. Controlled inactivation of recombinant viruses with vitamin B2. J. Virol. Methods 2008, 148, 132-145. [CrossRef]

32. Keil, S.D.; Ragan, I.; Yonemura, S.; Hartson, L.; Dart, N.K.; Bowen, R. Inactivation of severe acute respiratory syndrome coronavirus 2 in plasma and platelet products using a riboflavin and ultraviolet light-based photochemical treatment. Vox Sang. 2020, 115, 495-501. [CrossRef]

33. Zhou, Z.-Y.; Bi, X.-X. Experimental studies on the inactivation of HBV in blood via riboflavin photochemical treatment. Exp. Ther. Med. 2017, 13, 222-224. [CrossRef] [PubMed]

34. Dulbecco, R.; Freeman, G. Plaque production by the polyoma virus. Virology 1959, 8, 396-397. [CrossRef]

35. Moore, G.E. Culture of Normal Human Leukocytes. JAMA 1967, 199, 519. [CrossRef] [PubMed]

36. Eagle, H. Propagation in a fluid medium of a human epidermoid carcinoma, strain KB. Proc. Soc. Exp. Biol. Med. 1955, 89, 362-364. [CrossRef]

37. Martin, C.B.; Wilfong, E.; Ruane, P.; Goodrich, R.; Platz, M. An action spectrum of the riboflavin-photosensitized inactivation of Lambda phage. Photochem. Photobiol. 2005, 81, 474-480. [CrossRef]

38. Terrosi, C.; Anichini, G.; Docquier, J.D.; Gori Savellini, G.; Gandolfo, C.; Pavone, F.S.; Cusi, M.G. Efficient Inactivation of SARS-CoV-2 and Other RNA or DNA Viruses with Blue LED Light. Pathogens 2021, 10, 1590. [CrossRef]

39. Tomb, R.M.; Maclean, M.; Coia, J.E.; Graham, E.; McDonald, M.; Atreya, C.D.; MacGregor, S.J.; Anderson, J.G. New Proofof-Concept in Viral Inactivation: Virucidal Efficacy of $405 \mathrm{~nm}$ Light Against Feline Calicivirus as a Model for Norovirus Decontamination. Food Environ. Virol. 2016, 9, 159-167. [CrossRef]

40. Tomb, R.M.; Maclean, M.; Herron, P.R.; Hoskisson, P.A.; MacGregor, S.J.; Anderson, J.G. Inactivation of Streptomyces phage C31 by $405 \mathrm{~nm}$ light: Requirement for exogenous photosensitizers? Bacteriophage 2014, 4, e32129. [CrossRef]

41. Ho, D.T.; Kim, A.; Kim, N.; Roh, H.J.; Chun, W.-K.; Lee, Y.; Kim, D.-H. Effect of blue light emitting diode on viral hemorrhagic septicemia in olive flounder (Paralichthys olivaceus). Aquaculture 2020, 521, 735019. [CrossRef]

42. Rathnasinghe, R.; Jangra, S.; Miorin, L.; Schotsaert, M.; Yahnke, C.; García-Sastre, A. The virucidal effects of $405 \mathrm{~nm}$ visible light on SARS-CoV-2 and influenza A virus. Sci. Rep. 2021, 11, 19470. [CrossRef] [PubMed]

43. Kingsley, D.; Kuis, R.; Perez, R.; Basaldua, I.; Burkins, P.; Marcano, A.; Johnson, A. Oxygen-dependent laser inactivation of murine norovirus using visible light lasers. Virol. J. 2018, 15, 117. [CrossRef]

44. Tsugita, A.; Okada, Y.; Uehara, K. Photosensitized inactivation of ribonucleic acids in the presence of riboflavin. Biochim. Biophys. Acta-Nucleic Acids Protein Synth. 1965, 103, 360-363. [CrossRef]

45. Kingsley, D.H.; Perez-Perez, R.E.; Boyd, G.; Sites, J.; Niemira, B.A. Evaluation of 405-nm monochromatic light for inactivation of Tulane virus on blueberry surfaces. J. Appl. Microbiol. 2018, 124, 1017-1022. [CrossRef] [PubMed]

46. Skinner, H.H.; Bradish, C.J. Exposure to light as a source of error in the estimation of the infectivity of virus suspensions. J. Gen. Microbiol. 1954, 10, 377-397. [CrossRef]

47. Appleyard, G. The photosensitivity of Semliki Forest and other viruses. J. Gen. Virol. 1967, 1, 143-152. [CrossRef] [PubMed] 
48. Stasko, N.; Kocher, J.F.; Annas, A.; Henson, I.; Seitz, T.S.; Miller, J.M.; Arwood, L.; Roberts, R.C.; Womble, T.M.; Keller, E.G.; et al. Visible blue light inhibits infection and replication of SARS-CoV-2 at doses that are well-tolerated by human respiratory tissue. Sci. Rep. 2021, 11, 20595. [CrossRef]

49. Cutchins, E.C.; Dayhuff, T.R. Photoinactivation of measles virus. Virology 1962, 17, 420-425. [CrossRef]

50. de Santis, R.; Luca, V.; Näslund, J.; Ehmann, R.K.; de Angelis, M.; Lundmark, E.; Nencioni, L.; Faggioni, G.; Fillo, S.; Amatore, D.; et al. Rapid inactivation of SARS-CoV-2 with LED irradiation of visible spectrum wavelengths. J. Photochem. Photobiol. 2021, 8, 100082. [CrossRef]

51. Biasin, M.; Strizzi, S.; Bianco, A.; Macchi, A.; Utyro, O.; Pareschi, G.; Loffreda, A.; Cavalleri, A.; Lualdi, M.; Trabattoni, D.; et al. UV-A and UV-B Can Neutralize SARS-CoV-2 Infectivity. medRxiv 2021. [CrossRef]

52. Gardner, A.; Ghosh, S.; Dunowska, M.; Brightwell, G. Virucidal Efficacy of Blue LED and Far-UVC Light Disinfection against Feline Infectious Peritonitis Virus as a Model for SARS-CoV-2. Viruses 2021, 13, 1436. [CrossRef] [PubMed]

53. Zavestovskaya, I.N.; Guschin, V.A.; Nikiforova, M.A.; Siniavin, A.E.; Russu, L.I.; Cheshev, E.A.; Koromyslov, A.L.; Tupitsyn, I.M.; Fronya, A.A.; Grigoryeva, M.S. Experimental investigation of the effect ov UVA radiation on the coronavirus infective properties Bull. Lebedev Phys. Inst. 2021, 48, 195-199. [CrossRef]

54. Enwemeka, C.S.; Bumah, V.V.; Mokili, J.L. Pulsed blue light inactivates two strains of human coronavirus. J. Photochem. Photobiol. B 2021, 222, 112282. [CrossRef]

55. Lau, B.; Becher, D.; Hessling, M. High Intensity Violet Light (405 nm) Inactivates Coronaviruses in Phosphate Buffered Saline (PBS) and on Surfaces. Photonics 2021, 8, 414. [CrossRef]

56. Zupin, L.; Caracciolo, I.; Tricarico, P.M.; Ottaviani, G.; D'Agaro, P.; Crovella, S. Photobiomodulation therapy reduces viral load and cell death in ZIKV-infected glioblastoma cell line. Lasers Med. Sci. 2018, 33, 2011-2013. [CrossRef] [PubMed]

57. Zupin, L.; Caracciolo, I.; Tricarico, P.M.; Ottaviani, G.; D'Agaro, P.; Crovella, S. Antiviral properties of blue laser in an in vitro model of HSV-1 infection. Microbiol. Immunol. 2018, 62, 477-479. [CrossRef]

58. Vatter, P.; Hoenes, K.; Hessling, M. Photoinactivation of the Coronavirus Surrogate phi6 by Visible Light. Photochem. Photobiol. 2021, 97, 122-125. [CrossRef]

59. Vatter, P.; Hoenes, K.; Hessling, M. Blue light inactivation of the enveloped RNA virus Phi6. BMC Res. Notes 2021, $14,187$. [CrossRef]

60. Cartwright, S.F. A cytopathic virus causing a transmissible gastroenteritis in swine. II. Biological and serological studies. J. Comp. Pathol. 1966, 76, 95-106. [CrossRef]

61. Wallis, C.; Melnick, J.L. Irreversible photosensitization of viruses. Virology 1964, 23, 520-527. [CrossRef]

62. Wallis, C.; Trulock, S.; Melnick, J.L. Inherent photosensitivity of herpes virus and other enveloped viruses. J. Gen. Virol. 1969, 5, 53-61. [CrossRef] [PubMed]

63. Nemo, G.J.; Cutchins, E.C. Effect of visible light on canine distemper virus. J. Bacteriol. 1966, 91, 798-802. [CrossRef] [PubMed]

64. Richardson, T.B.; Porter, C.D. Inactivation of murine leukaemia virus by exposure to visible light. Virology 2005, 341, 321-329. [CrossRef] [PubMed]

65. Booth, J.C.; Stern, H. Photodynamic inactivation of rubella virus. J. Med. Microbiol. 1972, 5, 515-528. [CrossRef] [PubMed]

66. Zupin, L.; Gratton, R.; Fontana, F.; Clemente, L.; Pascolo, L.; Ruscio, M.; Crovella, S. Blue photobiomodulation LED therapy impacts SARS-CoV-2 by limiting its replication in Vero cells. J. Biophotonics 2021, 14, e202000496. [CrossRef] [PubMed]

67. Costa, L.; Faustino, M.A.F.; Neves, M.G.P.M.S.; Cunha, A.; Almeida, A. Photodynamic inactivation of mammalian viruses and bacteriophages. Viruses 2012, 4, 1034-1074. [CrossRef] [PubMed]

68. Wiehe, A.; O’Brien, J.M.; Senge, M.O. Trends and targets in antiviral phototherapy. Photochem. Photobiol. Sci. 2019, 18, 2565-2612. [CrossRef] 